\title{
FOREIGN LANGUAGE ACQUISITION: ATTITUDES OF YOUNG LEARNERS
}

\begin{abstract}
The following paper presents the results of a study of the attitude of young learners toward the introduction of the first foreign language (FL 1) into the second grade of one third of Slovenian public schools. We were interested whether there were statistically significant differences in the attitude of young learners toward the introduction of FL 1 related to their gender, age, and the school where FL 1 is taught. The results show that we can almost entirely accept RH1, whereas we can only partly accept RH 2 . As far as RH3 is concerned, the Bonferroni post-hoc test showed differences among ES Anton Ukmar, Koper, and ES Dragotin Kette, Ilirska Bistrica, ES Solkan and ES Voličina, where English is and was taught according to innovative teaching approaches (CLIL and the like).
\end{abstract}

Key words: age, gender, primary school, attitudes of young learners, first foreign language

\section{Introduction}

Foreign language teaching has received considerable attention due to its implications when ti comes to forming attitudes towards foreign language learning. The topic has already been dealt with as early as the late 1960s and 1970s (cf. Rivers 1965; Jakobovits 1970; Lambert 1972, and more recently, Pinter 2006, 2011). Cameron (2001: 1) claimed that teaching a foreign language to young foreign language learners is different from teaching adults or adolescents. Specifically, young learners are more enthusiastic and lively, and often they will have a go at an activity even if they do not quite understand the goals, and they are keener on pleasing the teacher rather than their peers. Moreover, young learners can rely on fewer resources as compared to adults and are less able to analyse the language in an abstract way (Pinter 2006: 17). Hence, young learners are not as capable of freely hypothesizing about features of another language, as adult learners are (Pinter 2006: 18).

Teaching a foreign language at an early age is a complex psychologicalpedagogical phenomenon, for it encompasses many factors of a positive learning outcome, including the learner's motivation for learning (Brumen et al. 2015: 29). Jazbec, Čagran and Lipavic Oštir (2016: 126) go even further by stating that motivation is a factor that greatly influences all forms of learning. Another equally important factor

*Istrska cesta 107, 6000 Koper, Slovenia; e-mail: tilen.smajla@guest.arnes.si 
is rich, plentiful and continued exposure to the language in question (Muñoz 2016). This is especially important in the first cycle of the primary school (grades 1 to 3 ) due to the perception that children start their educational process as a sort of tabula rasa. Besides, they possess natural abilities that help them learn in general and that boost the process of FL 1 learning to which they have already formed an attitude (Moon 2005: 115). Further, MacIntyre et al. (2002, as cited in Mihaljević Djigunović 2012: 57 ) believe that young learners vary significantly in their motivation, their positive attitude, as well as in presence or absence of learning difficulties.

It is characteristic of young learners in primary school that they are keen on learning a foreign language (FL), and that they are able to achieve good results if the learning takes place in an adequately intensive foreign language environment. From a very early age onwards they are confronted with their peers or older pupils, who may come from different language backgrounds and cultural settings. Further, they live in an environment with a high language input from different media (Ministrstvo za izobraževanje, znanost, kulturo in šport 2012).

There are multiple factors to be considered in early language learning, namely the context, the socio-political rationale, and the teacher expertise (Enever 2016: 355). Thus, contexts vary from extracurricular private language schools to public (state) school classrooms (Enever 2016: 353). Pedagogical approaches vary accordingly and therefore produce different outcomes. Where English is used as a medium of instruction (EMI), the language input is evenly intense throughout the core curriculum. In essence, this is similar to immersion approaches in the former colonial context of the British and French empires (ibid.). There is another reason why English has taken such a hold in the world, and that is the fact that, as Graddol (2006: 88-91) puts it: "English is not just an educational project, but also a political and economic one," meaning that governments in non-English speaking countries strive to linguistically equip their nations in order to be competitive on the global market. Besides the abovementioned factors, there are other important factors that we need to bear in mind, namely the individual factors (Richards and Rodgers 2014: 28). They include learning style preferences, affective factors, motivation, and learning strategies (ibid.). Although the above-mentioned issues deserve to be dealt with, the focus of this paper are the attitudes of young learners as described in the Problem section of the paper bellow.

\subsection{Research problem}

In the school year 2014/2015, the first foreign language (FL 1) was introduced into the second grade of one third of public primary schools in Slovenia. The trial phase lasted until 2016/2017, when all Slovenian primary schools joined in. No research into 
the attitudes of young learners toward the learning of FL 1 has been carried out on a national scale until now. It was therefore our intention to investigate the learners' perspectives on foreign language learning. The young age of the participants has made this research challenging, for there are many opinions on how to best motivate young learners for learning. According to some (Enever 2011) young learners come into the foreign language class with a certain attitude toward that language. That attitude is at times hard to change, since that is in the nature of attitude formation (Nastran Ule 1997: 115; Ule 2005; Wesely 2012).

\subsection{Research focus and research hypotheses}

The research focused on eight public primary schools across Slovenia in order to confirm the following research hypotheses: RH 1: There are statistically significant differences in the attitude of young learners toward the introduction of FL 1 regarding their gender; RH 2: There are statistically significant differences in the attitude of young learners toward the introduction of FL 1 regarding their age; RH 3: There are statistically significant differences in the attitude of young learners toward the introduction of FL 1 regarding the school, where FL 1 is taught.

\section{Research methodology}

\subsection{Research paradigm}

Research has been carried out in accordance with the guidelines of descriptive and causal, non-experimental quantitative research paradigm of pedagogical research. The results are presented in the tables below.

\subsection{Research sample}

The 61 Slovenian public primary schools that were chosen by the Ministry of Education, Science and Sport (Uradni list R Slovenije, 2014) to participate in the first round of the trial introduction of FL 1 into the second grade were contacted by mail. It turned out that only 59 out of 61 contacted primary schools $(96.7 \%)$ decided to carry out the project, while eight of them (13.5\%) agreed to accept our invitation to participate in the research. Printed materials (parental consent letters and questionnaires for the children in second grade) were sent out in January - February 2015 and in June 2015. The return rate in March 2015 was 257 second grade pupils, which was somewhat higher than the return rate in June 2015, which was 230 pupils. 


\subsection{Research instrument}

The research instrument used was the AMTB - Attitude/Motivation Test Battery (Gardner 2004). The original instrument has already been translated to various languages and applied in numerous studies in Brazil, Croatia, Japan, Poland, Rumania, and Spain. It consists of 104 items on a 7-point Likert scale. In this research, the participant responded by choosing 1, as I definitely do not agree to 7, as I absolutely agree, and thus expressed his/her attitude toward the object/situation. AMTB had already been standardised, yet considering the age of our respondents (second grade pupils are mostly 7 years old) only a part of the instrument was used (the part that met the aims of our research). In the follow up, the instrument was adapted, translated into Slovene and applied in the study. This resulted in an 11-item instrument, which was tested for validity using the factor analysis and reliability using the Cronbach alpha coefficient $(\alpha=0,719)$, which is good according to Field (2013: 640).

\subsection{Data analysis}

Data were processed by using SPSS IBM, v. 22 and 23. Two variables, Age and Gender, were considered as numerical variables. Assumptions of normality and homogeneity were tested using the Kurtosis and Skewness factors. Furthermore, a t-test, an analysis of variance, and, when statistically significant differences showed up in the analysis of variance, a post hoc test, were performed for the variable School.

\section{Results}

Eleven items were tackled in the analysis. The beginning of the empirical part of the research presented in this paper are the descriptive statistics, shown in the Appendix.

The Table in the Appendix shows that all participants share a positive attitude towards the learning of FL 1. Judging from the Mean values of the first period of sampling, the participants agreed most with the item "Learning English is a good thing" $(\bar{x}=6.3307)$. Further, the participants showed a high degree of agreement with the item "I am learning a foreign language in order to be able to communicate with others who use this language" $(\bar{x}=6.3152)$. The participants also quite agreed with the item "I learn a lot during my English class" $(\bar{x}=6.1128)$. High Mean values (between 5.2 and 5.9) can further be seen with the other items, which again confirms the positive attitudes towards the FL 1 learning, the exception being the item "I am not afraid of using English during class" ( $\bar{x}=4.7813)$, which implies a somewhat lower agreement with the item. The same item also shows a high s value (2.53). The second period of sampling, on the other hand, shows lower Mean values with seven items out 
of eleven, with the exception of the following items, the Mean value of which have risen compared to the first period of sampling: "I learn a lot during my English class," "Learning English is a good thing," "I am not afraid of using English outside class," and, "I am not afraid of using English during class."

In the follow-up, we focused on the analysis of the kurtosis and skewness coefficients. Our aim was to eliminate those coefficients, which represent an anomaly to the normal distribution. The results of the kurtosis and skewness coefficients analysis based on the sample of 257 pupils show an uneven distribution with five items, the values of which are significantly above $|2|$, hence these items were not included in further analyses. The items are as follows: "I am learning a foreign language in order to be able to communicate with others who use this language" (KURT: 5.217, SKEW: -2.393), "English is interesting" (KURT: 2.981), "My attitude toward the learning of English is positive" (KURT: 3.173), "I learn a lot during my English class" (KURT: 3.189), and "Learning English is a good thing" (KURT: 5.246, SKEW: -2.511). The results of the kurtosis and skewness coefficients analysis based on the sample of 230 pupils show an uneven distribution with three items, which were consequently not included in the further analyses. The items are as follows: "I am learning a foreign language in order to be able to communicate with others who use this language" (KURT: 4.089, SKEW: -2.100), "I learn a lot during my English class" (KURT: 4.378, SKEW: -2.165), and "Learning English is a good thing" (KURT: 7.177, SKEW: -2.731).

The following part of the paper is dedicated to the presentation of the results regarding the attitudes of primary school pupils to the introduction of FL 1. Our aim was to establish potential statistically significant differences in attitudes of primary school pupils to the introduction of FL 1 regarding their gender. A t-test was performed in the attempt to confirm the hypothesis. Statistically significant differences are highlighted in bold print. Results of the analysis for the first period of sampling are presented in Table 1 bellow.

\begin{tabular}{|c|c|c|c|c|c|c|}
\hline Items & & $\bar{x}$ & F & $\mathrm{P}$ & $\mathrm{t}$ & $2 \mathrm{P}$ \\
\hline \multirow{2}{*}{$\begin{array}{l}\text { My attitude to people speaking } \\
\text { English is good. }\end{array}$} & females & 5.75 & \multirow{2}{*}{1.729} & \multirow{2}{*}{0.290} & \multirow{2}{*}{-1.253} & \multirow{2}{*}{.212} \\
\hline & males & 5.47 & & & & \\
\hline \multirow{2}{*}{$\begin{array}{l}\text { Learning English is a good } \\
\text { thing. }\end{array}$} & females & 6.49 & \multirow{2}{*}{4.184} & \multirow{2}{*}{0.042} & \multirow{2}{*}{0.972} & \multirow{2}{*}{.330} \\
\hline & males & 6.21 & & & & \\
\hline \multirow{2}{*}{$\begin{array}{l}\text { I am not afraid of using English } \\
\text { outside class. }\end{array}$} & females & 4.60 & \multirow{2}{*}{1.348} & \multirow{2}{*}{0.247} & \multirow{2}{*}{0.977} & \multirow{2}{*}{.334} \\
\hline & males & 4.91 & & & & \\
\hline
\end{tabular}


Tilen Smajla

\begin{tabular}{|c|c|c|c|c|c|c|}
\hline \multirow{2}{*}{$\begin{array}{l}\text { My English class is/my English } \\
\text { teacher is interesting. }\end{array}$} & females & 6.21 & \multirow{2}{*}{13.025} & \multirow{2}{*}{0.000} & \multirow{2}{*}{-2.317} & \multirow{2}{*}{.016} \\
\hline & males & 5.68 & & & & \\
\hline \multirow{2}{*}{$\begin{array}{l}\text { I am not afraid of using English } \\
\text { during class. }\end{array}$} & females & 5.22 & \multirow{2}{*}{0.885} & \multirow{2}{*}{0.348} & \multirow{2}{*}{.383} & \multirow{2}{*}{.706} \\
\hline & males & 5.33 & & & & \\
\hline \multirow{2}{*}{$\begin{array}{l}\text { Learning English makes my } \\
\text { parents happy. }\end{array}$} & females & 5.53 & \multirow{2}{*}{0.003} & \multirow{2}{*}{0.956} & \multirow{2}{*}{.225} & \multirow{2}{*}{.799} \\
\hline & males & 5.60 & & & & \\
\hline
\end{tabular}

Table 1. Differences in primary school pupils' attitudes to FL 1 introduction with regard to their gender (first period of sampling)

Results presented in Table 1 show only one statistically significant difference in primary school pupils' attitudes towards the introduction of FL 1 regarding the variable gender in the first period of sampling (January-February 2015). Statistically significant difference with the degree lower than $0.05 \%$ was established with the item: "My English class is/my English teacher is interesting" $(p=0.016)$. We can therefore confirm hypothesis 1 with one of eleven items. We can also claim the female pupils to be have a more positive attitude towards FL lessons.

The results of the t-test for the second period of sampling are presented in Table 2.

\begin{tabular}{|c|c|c|c|c|c|c|}
\hline Items & & $\bar{x}$ & $\mathrm{~F}$ & $\mathrm{P}$ & $\mathrm{t}$ & $2 \mathrm{P}$ \\
\hline \multirow{2}{*}{$\begin{array}{l}\text { My attitude to people speaking } \\
\text { English is good. }\end{array}$} & females & 5.98 & \multirow{2}{*}{17.176} & \multirow{2}{*}{0.000} & \multirow{2}{*}{-2.568} & \multirow{2}{*}{.007} \\
\hline & males & 5.33 & & & & \\
\hline \multirow{2}{*}{ English is interesting. } & females & 6.06 & \multirow{2}{*}{10.462} & \multirow{2}{*}{0.001} & \multirow{2}{*}{-2.177} & \multirow{2}{*}{.023} \\
\hline & males & 5.54 & & & & \\
\hline \multirow{2}{*}{ I want to learn English. } & females & 6.05 & \multirow{2}{*}{5.146} & \multirow{2}{*}{0.024} & \multirow{2}{*}{-2.132} & \multirow{2}{*}{.034} \\
\hline & males & 5.55 & & & & \\
\hline \multirow{2}{*}{$\begin{array}{l}\text { My attitude toward the learning } \\
\text { of English is positive. }\end{array}$} & females & 6.12 & \multirow{2}{*}{10.127} & \multirow{2}{*}{0.002} & \multirow{2}{*}{-2.375} & \multirow{2}{*}{.018} \\
\hline & males & 5.58 & & & & \\
\hline \multirow{2}{*}{$\begin{array}{l}\text { My English class is/my English } \\
\text { teacher is interesting. }\end{array}$} & females & 5.94 & \multirow{2}{*}{12.061} & \multirow{2}{*}{0.001} & \multirow{2}{*}{2.358} & \multirow{2}{*}{.019} \\
\hline & males & 5.33 & & & & \\
\hline \multirow{2}{*}{$\begin{array}{l}\text { I am not afraid of using English } \\
\text { during class. }\end{array}$} & females & 5.10 & \multirow{2}{*}{5.425} & \multirow{2}{*}{0.021} & \multirow{2}{*}{1.832} & \multirow{2}{*}{.069} \\
\hline & males & 5.68 & & & & \\
\hline \multirow{2}{*}{$\begin{array}{l}\text { Learning English makes my } \\
\text { parents happy. }\end{array}$} & females & 5.48 & \multirow{2}{*}{2.385} & \multirow{2}{*}{0.124} & \multirow{2}{*}{-.522} & \multirow{2}{*}{.602} \\
\hline & males & 5.33 & & & & \\
\hline
\end{tabular}

Table 2. Differences in primary school pupils' attitudes to FL 1 introduction with regard to their gender (second period of sampling) 
Results presented in Table 2 are as follows: the second period of sampling (June 2015) produced five statistically significant differences in primary school pupils' attitudes towards FL 1 introduction regarding the variable gender. Items "My attitude to people speaking English is good" ( $p=0.007)$, "English is interesting" $(p=0.023)$, "I want to learn English" ( $\mathrm{p}=0.034)$, "My attitude toward the learning of English is positive" ( $p=0.018$ ), as well as "My English class is/my English teacher is interesting" $(\mathrm{p}=0.019)$ are highlighted as those in which the degree of statistical significance is lower than $0.05 \%$. Once we consider the two periods of sampling the obviously more positive attitude towards FL 1 learning can be found with female pupils, which ought to send an important message to FL 1 teachers, policy makers, and school authorities alike. Hence, we can confirm Hypothesis 1 in case of five items out of eleven.

In the following part of the paper we focus on the analysis of the primary school pupils' attitudes towards FL 1 introduction with regards to their age. The result of the t-tests are presented in Table 3 bellow.

Results of the t-test for both periods of sampling show only one statistically significant difference in primary school pupils' attitudes towards the introduction of FL 1 with regard to the pupils' age in each period. The item in question with the degree of statistical agreement lower than 0.05 in the first period of sampling is: "I am not afraid of using English outside class" ( $p>0.035$ ), whereas the result of the t-test in the second period of sampling being somewhat different. The item under scrutiny is in this case: "English is interesting" $(\mathrm{p}=0.030)$. Considering the above results we can accept Hypothesis 2 with regard to only two items.

The following part of the paper focuses on the analysis of the primary school pupils' attitudes towards FL 1 introduction regarding the school where FL 1 is taught. The results of the ANOVA test for both periods of sampling are presented in Table 4 bellow. The statistically significant differences are highlighted in bold. 


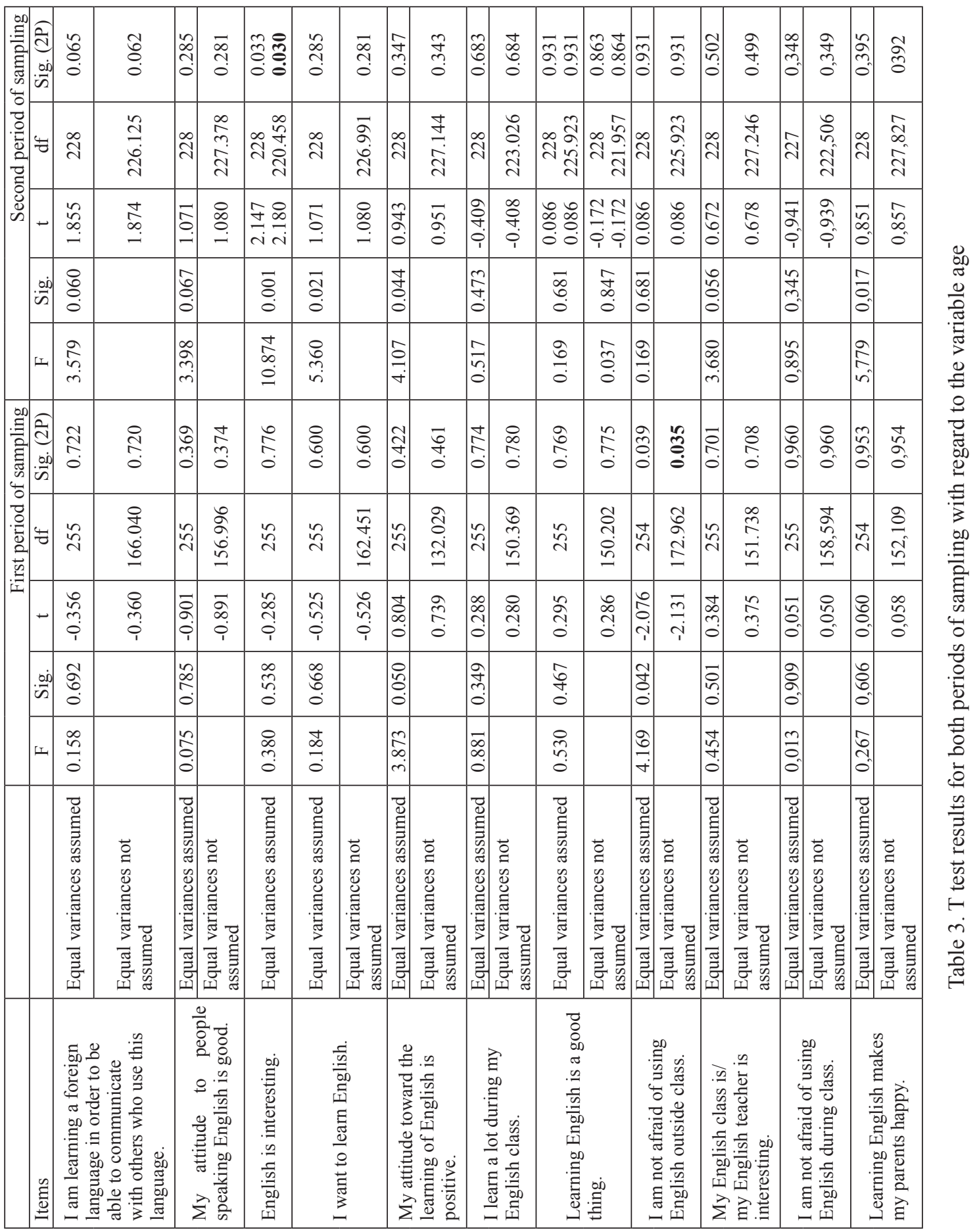


FOREIGN LANGUAGE ACQUISITION: ATTITUDES OF YOUNG LEARNERS

\begin{tabular}{|c|c|c|c|c|c|}
\hline \multirow{2}{*}{\multicolumn{2}{|c|}{ Items }} & \multicolumn{2}{|c|}{$\begin{array}{l}\text { First period of } \\
\text { sampling }\end{array}$} & \multicolumn{2}{|c|}{$\begin{array}{l}\text { Second period } \\
\text { of sampling }\end{array}$} \\
\hline & & \multirow{2}{*}{$\frac{F}{1.865}$} & \multirow{2}{*}{$\begin{array}{c}\text { Sig. } \\
0.076\end{array}$} & \multirow{2}{*}{$\frac{F}{4,893}$} & \multirow{2}{*}{$\begin{array}{l}\text { Sig. } \\
\mathbf{0 , 0 0 0}\end{array}$} \\
\hline $\begin{array}{l}\text { I am learning a foreign language in } \\
\text { order to be able to communicate with }\end{array}$ & Between Groups & & & & \\
\hline others who use this language. & Within Groups & & & & \\
\hline \multirow{2}{*}{$\begin{array}{l}\text { My attitude to people speaking English } \\
\text { is good. }\end{array}$} & Between Groups & 1.694 & 0.111 & 1,526 & 0,170 \\
\hline & Within Groups & & & & \\
\hline \multirow{2}{*}{ English is interesting. } & Between Groups & 1.475 & 0.177 & 1,432 & 0,203 \\
\hline & Within Groups & & & & \\
\hline \multirow{2}{*}{ I want to learn English. } & Between Groups & 1.586 & 0.140 & 2,582 & 0,019 \\
\hline & Within Groups & & & & \\
\hline \multirow{2}{*}{$\begin{array}{l}\text { My attitude toward the learning of } \\
\text { English is positive. }\end{array}$} & Between Groups & 0.979 & 0.447 & 1,456 & 0,194 \\
\hline & Within Groups & & & & \\
\hline \multirow{2}{*}{ I learn a lot during my English class. } & Between Groups & 1.893 & 0.071 & 2,600 & $\mathbf{0 , 0 1 9}$ \\
\hline & Within Groups & & & & \\
\hline \multirow{2}{*}{ Learning English is a good thing. } & Between Groups & 0.636 & 0.726 & 2,023 & 0,064 \\
\hline & Within Groups & & & & \\
\hline \multirow{2}{*}{$\begin{array}{l}\text { I am not afraid of using English } \\
\text { outside class. }\end{array}$} & Between Groups & 2.911 & 0.006 & 1,992 & 0,068 \\
\hline & Within Groups & & & & \\
\hline \multirow{2}{*}{$\begin{array}{l}\text { My English class is/my English teacher } \\
\text { is interesting. }\end{array}$} & Between Groups & 0.642 & 0.721 & 2,536 & $\mathbf{0 , 0 2 1}$ \\
\hline & Within Groups & & & & \\
\hline \multirow{2}{*}{$\begin{array}{l}\text { I am not afraid of using English } \\
\text { during class. }\end{array}$} & Between Groups & 2.990 & 0.005 & 2,276 & $\mathbf{0 , 0 3 8}$ \\
\hline & Within Groups & & & & \\
\hline \multirow{2}{*}{$\begin{array}{l}\text { Learning English makes my parents } \\
\text { happy. }\end{array}$} & Between Groups & 4.406 & 0.000 & 2,902 & 0,010 \\
\hline & Within Groups & & & & \\
\hline
\end{tabular}

Table 4. Result of the analysis of variance of the pupils' attitude toward FL 1 introduction regarding the school, where FL 1 is taught 
Results of the ANOVA for both of the periods of sampling show statistically significant differences in primary school pupils' attitudes towards the introduction of FL 1 regarding the school where FL 1 is taught in the cases of the following items: 8 (I am not afraid of using English outside class.) in the first period of sampling, 9 (My English class is/my English teacher is interesting.) in the second period of sampling, 10 (I am not afraid of using English during class.), and 11 (Learning English makes my parents happy.). Statistically significant differences in primary school pupils' attitudes were found with item 8 (I am not afraid of using English outside class.). Items 1, 3, 4, 5,6 , and 7 could not be included in the analysis based on their high values of kurtosis and skewness coefficients (see Appendix 1). The Bonferroni post hoc tests came up with the following results: in the first period of sampling the analysis highlighted three items with statistically significant differences between primary schools: item 8 (Primary School Solkan compared to Primary School Anton Ukmar Koper $\mathrm{p}=0.002)$, item 10 (Primary School Solkan compared to Primary School Anton Ukmar Koper $\mathrm{p}=0.001$ ), and item 11 (Primary School Anton Ukmar Koper compared to Primary School Solkan $\mathrm{p}=0.004$, and Primary School Voličina compared to Primary School Solkan $\mathrm{p}=0.009$ ). The Bonferroni post hoc test for the second period of sampling showed a different set of statistically significant differences between schools, although the items were the same two (item 8 and 10) that appeared among the statistically significant ones from the first period of sampling. Hence, we can partly confirm Hypothesis 3.

\section{Discussion and conclusions}

The purpose of our research was to find out whether the attitude of primary school pupils towards FL 1 significantly changed depending on their gender, age and the school where FL 1 is taught. Judging from the results of statistical analyses, attitudes play an important role in the learning process. Nastran Ule maintains (1997) that the formation of attitudes can never be looked upon as an out-of-context phenomenon. She also claims that we constantly compare, negotiate and construct our reality, our motifs and feelings with regard to other people (ibid.). Ule (2005: 116) also claims attitudes to be "an important psychological phenomenon due to the fact they represent and comprise the complex interdependentness of human psyche and his/her social behaviour." Gardner and Lambert (1972) claim that research in attitudes towards the foreign language learning is nowadays considered an important factor in successful language teaching. These authors emphasized an important link between language production on one hand, and a positive attitude as well as motivation on the other hand (ibid.).

We had not assumed any differences in primary school pupils' attitudes towards the FL 1 introduction depending on their gender, yet the analyses proved otherwise. 
Gender obviously plays an important role in FL 1 learning, and as it turned out, it was the female pupils whose attitudes towards the FL 1 introduction varied least in the course of the first year. Consequently, FL 1 teachers will need to put in more effort into the FL classes in order to maintain the level of the learning motivation evenly high during the entire school year, with emphasis on the male pupils, who tend to be less motivated. Moreover, we were not surprised with the results of the research into the pupils' age and its influence on FL 1 learning. Some pupils turned 8 towards the end of the school year, but the difference in age seemed not to have had a major impact on the attitude change. What actually did have a significant influence upon the pupils' attitudes towards FL 1 learning is the school where FL 1 was taught, in which case we ought to bear in mind that it is the whole school setting, not only the FL 1 teacher, that makes the difference.

The findings of our research can hence be implemented in further research in the field of early foreign language learning and teaching, as well as in forming guidelines for successful foreign language teaching throughout the entire school year. What is obviously of greater importance for a young foreign language learner is whether or not the teaching approach or teaching methods cater for the young foreign language learner's needs, whether or not a young foreign language learner feels appreciated in the learning environment, and whether or not a young foreign language learner has the feeling of accomplishment after a FL class. Consequently, foreign language teachers ought to rethink their motivation strategies as well as teaching methods and constantly adjust them to the pupils they are dealing with.

\section{References}

Brumen, M., P. Kolbl Ivanjšič and M. Pšunder (2015). Pedagoški vidiki poučevanja nejezikovnih predmetov v tujem jeziku. Revija za elementarno izobraževanje, $8,(1 / 2), 27-42$.

Cameron, L. (2001). Teaching Languages to Young Learners. Cambridge: Cambridge University Press.

Enever, J. (ed.) (2011). ELLiE: Early language learning in Europe. London: The British Council. (15 May 2016) <https://www.researchgate.net/publication/265383696_ ELLiE_Early_language_learning_in_Europe.>.

Enever, J. (2016). Primary ELT: issues and trends. In: G. Hall (ed.), The Routledge Handbook of English Language Teaching, New York: Routledge Handbooks, 353-364.

Field, A. (2005). Discovering statistics using SPSS. London: Sage Publications Ltd. 
Gardner, Robert C. (2004). The Attitude/Motivation Test Battery. (8 July 2014) <http:// publish.uwo.ca/ gardner/docs/englishamtb.pdf>.

Gardner, R. C. and W. E. Lambert (1972). Attitudes and Motivation in Second Language Learning. Rowley, MA: Newbury House.

Graddol, D. (2006). English Next. United Kingdom: British Council.

Jakobovits, L. A. (1969). Measuring foreign language aptitude and attitude. Hawaii: University of Hawaii.

Jazbec, S., B. Čagran, and A. Lipavic Oštir (2016). Early Foreign Language Learning from the Children's Perspective. The New Educational Review, 45(3), 124136. (22 May 2017) <http://www.educationalrev.us.edu.p1/dok/volumes/ tner_3_2016.pdf>.

Lambert, W. E. (1972). Language, psychology, and culture. Vol. 5. Stanford, CA: Stanford University Press.

Lipavic Oštir, A. and S. Jazbec n. d.. Zgodnje učenje tujega jezika z vidika nekaterih teorij. (10 December 2014) <http://www.zrss.si/projektiess/skladisce/ sporazumevanje_v_tujih_jezikih/tuj\%20jezik\%20v\%20prvem\%20triletju/ Strokovni\%20\%C4\%8Dlanki\%20in\%20prevodi/zgodnje_ucenje_tujega_ jezika_z_vidika_razlicnih_teorij_lipavic_ostir.pdf $>$.

Mihaljević Djigunović, J. (2012). Odnos in motiviranost mlajših učencev do učenja tujega jezika. CEPS Journal, 2(3), 56-72.

Ministrstvo za izobraževanje, znanost in šport. 2012. Učni načrt za tuji jezik v prvem vzgojno-izobraževalnem obdobju osnoven šole. (13 May 2014) <http://www. mizs.gov.si/fileadmin/mizs.gov.si/pageuploads/podrocje/os/prenovljeni_UN/ Tuji_jezij_v_prvem_VI_obdobju.pdf $>$.

Ministrstvo za kulturo Republike Slovenije. 2013. Resolucija o nacionalnem programu za jezikovno politiko 2014-2018. (10 May 2014) <http://www.mk.gov.si/ fileadmin/mk.gov.si/pageuploads/Ministrstvo/Zakonodaja/2013/Resolucija_-sprejeto_besedilo_15.7.2013_.pdf $>$.

Moon, J. (2005). Children Learning English. A Guidebook for English Language Teachers. Oxford: Macmillan.

Muñoz, C. (2016). What is the best age to learn a second/foreign language? Canadian Modern Language Review. (22 May 2017) <http://www.utpjournals.press/ journals/cmlr/Munoz>.

Nastran-Ule, M. (1997). Temelji socialne psihologije. Ljubljana: Znanstveno in publicistično središče.

Pinter, A. (2006). Teaching Young Language Learners. Oxford: Oxford University Press. 
Pinter, A. (2011). Children Learning Second Languages. London: Palgrave Macmillan. Uradni list RS, št. 20/14. Pravilnik o postopnem uvajanju prvega tujega jezika v 2. razred osnovne šole. 2014. (23 May 2016) <http://pisrs.si/Pis.web/ pregledPredpisa?id=PRAV11951>.

Richards, J. S. and T. S Rodgers (eds.) (2014). The nature of approaches and methods in language teaching. In: J. C. Richards and T. S. Rodgers (eds), Approaches and Methods in Language Teaching, Third Edition. Cambridge: Cambridge University Press, 28-44.

Rivers, W. M. (1965). The psychologist and the foreign-language teacher. British Journal of Educational Studies, 12(2), 228-229.

Ule, M. (2005). Socialna psihologija. Ljubljana: Fakulteta z družbene vede.

Wesely, P. M. (2012). Learner Attitudes, Perceptions, and Beliefs in Language Learning. Foreign Language Annals, 45, 98-117. doi:10.1111/j.1944-9720.2012.01181.x 
Appendix 1

Table 5. Descriptive statistics

\begin{tabular}{|c|c|c|c|c|c|c|c|c|c|c|c|c|}
\hline & $=$ & ఠి & ఠ్ల & ্ָ & 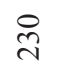 & ఠ్లి & ণ্సి & $\underset{\overbrace{}}{\sim}$ & ণ্ণ & $\underset{\sim}{\sim}$ & సે & ণ্సి \\
\hline & $\begin{array}{l}3 \\
\frac{1}{1} \\
\frac{1}{n}\end{array}$ & 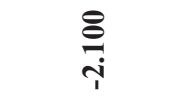 & 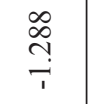 & 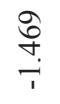 & $\underset{\substack{\text { gे } \\
i}}{ }$ & $\underset{\stackrel{+}{f}}{\stackrel{+}{+}}$ & $\underset{:}{\stackrel{6}{i}}$ & $\stackrel{\bar{r}}{\stackrel{\tilde{i}}{i}}$ & $\begin{array}{l}\hat{\imath} \\
\hat{i}\end{array}$ & $\stackrel{0}{\stackrel{m}{\rightarrow}}$ & $\underset{\nearrow}{\stackrel{\Xi}{-}}$ & $\underset{ت}{\vec{J}}$ \\
\hline & 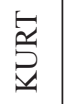 & 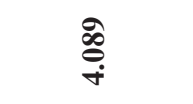 & $\begin{array}{l}\infty \\
\stackrel{\infty}{+} \\
0 \\
0\end{array}$ & $\stackrel{2}{\stackrel{2}{7}}$ & $\stackrel{8}{\rightleftarrows}$ & 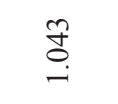 & $\underset{\substack{\infty \\
\stackrel{\infty}{+}}}{ }$ & $\stackrel{5}{\stackrel{5}{7}}$ & \begin{tabular}{l}
0 \\
\hdashline \\
\hdashline
\end{tabular} & $\begin{array}{c}\infty \\
\text { ֻे } \\
0\end{array}$ & $\begin{array}{l}8 \\
\stackrel{0}{0} \\
\stackrel{1}{+}\end{array}$ & $\begin{array}{l}\text { ָे } \\
\text { ஸ़ }\end{array}$ \\
\hline & $\infty$ & \begin{tabular}{l}
$\stackrel{n}{f}$ \\
\multirow{d}{f}{} \\
$\stackrel{+}{+}$
\end{tabular} & $\begin{array}{l}\stackrel{\hat{o}}{\sigma} \\
\text { a }\end{array}$ & 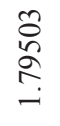 & 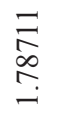 & $\begin{array}{l}\vec{\forall} \\
\stackrel{\infty}{\infty} \\
\stackrel{D}{-}\end{array}$ & 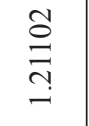 & 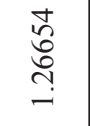 & $\begin{array}{l}\overrightarrow{+} \\
\stackrel{n}{n} \\
\end{array}$ & \begin{tabular}{l}
$\infty$ \\
\multirow{2}{*}{} \\
$\hat{\sigma}$ \\
$i$
\end{tabular} & 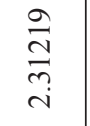 & $\begin{array}{l}\overline{\vec{J}} \\
\underset{i}{\sim}\end{array}$ \\
\hline 駡 号 & $1 x$ & $\begin{array}{l}\stackrel{0}{0} \\
\frac{0}{0}\end{array}$ & $\begin{array}{l}\stackrel{D}{1} \\
\infty \\
i n \\
i n\end{array}$ & 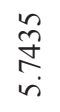 & 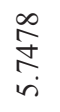 & $\frac{m}{\hat{a}}$ & 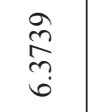 & 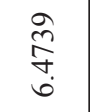 & $\begin{array}{l}\frac{9}{8} \\
\dot{8} \\
\dot{i n}\end{array}$ & $\begin{array}{l}\hat{\widehat{D}} \\
\stackrel{n}{n} \\
i n\end{array}$ & $\begin{array}{l}\text { ते } \\
\text { ড̦ } \\
\text { in }\end{array}$ & $\frac{m}{\vec{m}}$ \\
\hline & $=$ & $\hat{n}$ & $\hat{n}$ & $\hat{\imath}$ & $\hat{n}$ & $\hat{n}$ & $\hat{n}$ & $\hat{\tilde{n}}$ & ڤె & $\hat{n}$ & $\hat{n}$ & ڤె \\
\hline & $\begin{array}{l}3 \\
\frac{3}{1} \\
\frac{1}{n}\end{array}$ & ஸึ & $\stackrel{\hat{n}}{\rightarrow}$ & 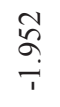 & $\stackrel{\substack{0 \\
\rightarrow}}{\rightarrow}$ & $\begin{array}{l}\mathscr{\infty} \\
\infty \\
\stackrel{\infty}{\rightarrow}\end{array}$ & 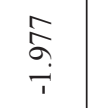 & $\begin{array}{l}\overline{\text { nn }} \\
\text { i }\end{array}$ & $\begin{array}{l}m \\
\hat{n} \\
i\end{array}$ & 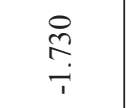 & $\begin{array}{l}\text { ầ } \\
\stackrel{i}{i}\end{array}$ & $\stackrel{\widehat{ָ}}{+}$ \\
\hline & 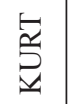 & $\underset{\vec{n}}{\vec{n}}$ & 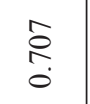 & $\begin{array}{l}\bar{\infty} \\
\stackrel{3}{i}\end{array}$ & $\stackrel{\circ}{\frac{1}{i}}$ & $\stackrel{m}{=}$ & $\stackrel{\infty}{\stackrel{\infty}{m}}$ & $\begin{array}{l}\stackrel{0}{*} \\
\text { ì } \\
\text { ம. }\end{array}$ & $\stackrel{\text { ̧े }}{\stackrel{7}{-}}$ & 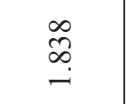 & $\begin{array}{l}\stackrel{9}{1} \\
\infty \\
i \\
i\end{array}$ & $\stackrel{n}{0}$ \\
\hline & $\infty$ & $\begin{array}{l}\stackrel{+}{\infty} \\
\stackrel{\infty}{\sim} \\
\stackrel{-}{-}\end{array}$ & 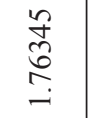 & \begin{tabular}{l}
$\stackrel{7}{7}$ \\
\multirow{2}{*}{} \\
$\stackrel{-}{-}$
\end{tabular} & $\begin{array}{l}\hat{a} \\
8 \\
0 \\
\text { I. }\end{array}$ & $\begin{array}{l}\stackrel{\sigma}{O} \\
\stackrel{+}{*} \\
\stackrel{n}{-}\end{array}$ & $\begin{array}{l}8 \\
\hat{n} \\
n \\
n\end{array}$ & $\begin{array}{l}\infty \\
\infty \\
0 \\
\\
\end{array}$ & $\begin{array}{c}\hat{y} \\
\stackrel{y}{n} \\
\text { in }\end{array}$ & $\underset{\hat{\sigma}}{\hat{\infty}}$ & $\begin{array}{l}\infty \\
\infty \\
0 \\
0 \\
\\
i\end{array}$ & 令 \\
\hline 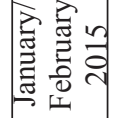 & $1+$ & $\frac{\tilde{n}}{\tilde{n}}$ & $\begin{array}{l}\vec{D} \\
\vec{n} \\
i n\end{array}$ & & $\begin{array}{l}\hat{\sigma} \\
\vdots \\
\vdots \\
i\end{array}$ & $\frac{\mathscr{n}}{n}$ & $\underset{\Xi}{\stackrel{\infty}{\Xi}}$ & 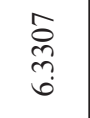 & 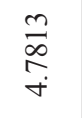 & $\begin{array}{l}8 \\
\stackrel{\circ}{\circ} \\
\text { in }\end{array}$ & 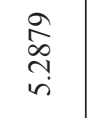 & $\begin{array}{l}\vec{\infty} \\
\hat{n} \\
i n\end{array}$ \\
\hline & 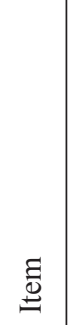 & 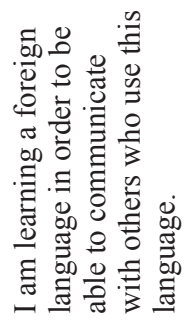 & 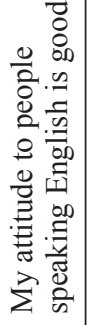 & 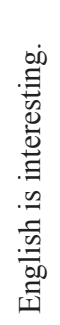 & 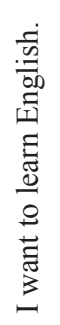 & 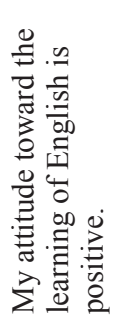 & 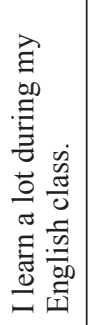 & 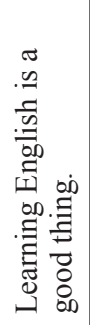 & 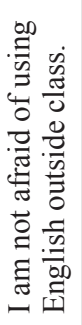 & 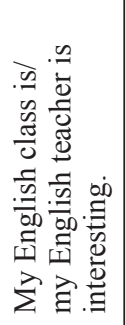 & 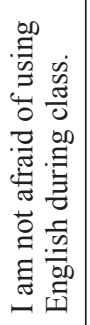 & 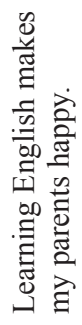 \\
\hline
\end{tabular}

$\bar{x}$ - Mean, $\mathrm{s}$ - standard deviation, CURT - coefficient of kurtosis, SKEW - coefficient of skewness, $n$ - sample 